\title{
National Identity and Crisis of Integration in Multi-Ethnic Nigeria: An Existentialist Perspective
}

\author{
Marcel Ikechukwu Sunday Onyibor \\ Department of General Studies, School of Sciences, Federal University of Technology Akure, Akure, Nigeria \\ Email: misonyibor@futa.edu.ng, marcelifeanyi@yahoo.com
}

Received 24 March 2015; accepted 17 January 2016; published 20 January 2016

Copyright ( 2016 by author and Scientific Research Publishing Inc.

This work is licensed under the Creative Commons Attribution International License (CC BY).

http://creativecommons.org/licenses/by/4.0/

cC) (7) Open Access

\begin{abstract}
One would expect Nigeria after attaining a century old as a nation state on January 2014 to have overcome the problem of national identity and crisis of integration resulting from its multiethnic composition, but recent events have revealed that this desired status is yet to be fully attained. In fact, there have been continuous agitation by various ethnic nationalities ranging from militancy in the Niger Delta south region which has transformed into oil bunkering, armed robbery and organized kidnapping spreading to the southeastern and western part of the country; to various forms of religious fanaticism in the northeastern axis which recently metamorphoses into terrorism and kidnapping as socio-political characteristic of the present Nigeria society, the question that arises is how far Nigeria as a nation state has put itself on the part of achieving national identity and integration of its multiethnic nationalities into a united nation state. Through the methodological approach of historico-logical analysis of identified factors militating against the above objective, this article will proffer the existentialist principle of inter-subjectivity predicated on some tested democratic values such as rule of law, justice, equality, fairness and freedom as panacea for attaining national identity and resolving crisis of integration in Nigeria.
\end{abstract}

\section{Keywords}

Existentialism, Identity, Integration, Inter-Subjectivism, Multiethnic

\section{Introduction}

Identity can be described as the state of having unique identifying characteristics held by no other person or thing. In other words, it is the individual characteristic by which a person or thing is recognized. It is what it 
means to be who one is (Burke2003a:1) and often associated with labels for social positions or roles. Roles label convey meanings and expectations for behaviors that have evolved from countless interactions among people in a social system. Roles are externally defined by the expectations of others, but individuals define their own identities internally as they accept or reject social role expectations as a part of people who they are (Stryker \& Burke 2000). Once an individual has accepted and internalized expectations for a role as a part of his/her identity, that identity becomes a cognitive frame work interpreting new experiences.

Social identity theory postulates that social behavior exists from the spectrum of purely interpersonal to the purely intergroup where personal identity is salient. The individual will relate with others in an interpersonal manner depending on their character traits and personal relationship existing between the individuals. However, under certain conditions social identity is more salient than personal identity in self conception. When this is the case and behavior is qualitatively different, it then becomes group behavior. Social identities are associated with normative rights, obligations and sanctions which within specific collectivities form roles. (Giddens) Jary and Jary (1991) defined identity as a sense of self that developed as the child differentiates from parents and family and took a place in the society. It refers to the sense that someone has of who they are, of what is most important about them. Important sources of identity are likely to include nationality, ethnicity, sexuality, class, etc.

Although, it is the individual who has identity, identity is related to social groups to which the individual belongs and with which they identify. However, there is no perfect match between how a person thinks of himself and how others see him. Personal identity may be different from social identity. For instance, a person perceived by others to be male may see himself as a woman trapped in a man's body. In fact, post instrumentalist and post modernist theories of identity have adopted very different views. They tend to suggest that people's identities have many different facets that they frequently change and contain considerable contradictions. Thus, this perspective suggests that people actively create their own identities. Identities are no longer reducible simply to the social groups to which people belong. People have a great deal of choice about what social groups to join, to some writers most individuals in contemporary societies no longer have a stable sense of identity at all-their identity is fragmented.

In economic sphere, Akerlof and Kranton incorporate social identity factor to principal agent model. Their main conclusion is that when the agent considers him an insider, he will maximize his identity utility by exerting high level effort comparable with his prescribed behavior. On the other hand, if he considers himself an outsider, he will require a higher wage to compensate his loss for behavior different from prescribed behaviors. The concept of identity is also closely related the idea of culture. Identity can be formed through the cultures and subcultures to which the person belong or in which he participates. However, different theories of identity see the relationship between culture and identity in rather different perspective. Those influenced by modern theories of culture are more likely to see identity as originating in a fairly straight forward way from involvement in particular culture and subculture. For instance, people living in Nigeria would be expected to have a strong sense of Nigerian identity. Theories influenced by post modernism tend to stress the complexity of being Nigerian and the diverse ways in which Nigerian people from different ethnic groups interpret Nigerian identity. Stephen Frosh (1999) is of the view that identity draws from culture but is not simply formed by it. In fact recent Sociological and Psychological theory has stressed that a person's identity is something multiple and potentially fluid, constructed through experience and linguistically coded. The process of identity construction is therefore one upon which the contradictions and dispositions of the surrounding socio-cultural environment has a profound impact.

Cultural identity is the identity of a group or culture of an individual as far as one is influenced by belonging to that group or culture. Cultural identity is similar to and has overlaps with, but is not synonymous with politics. It is influenced by several factors such as ones religion, ancestry, skin colour, language, class, education, profession, skill, family and politics etc., these factors contribute to the development of one's identity. Thus, Elebeke, (2010: p. 22) explains it as a process located in the core of the individual and yet also in the core of his communal culture, a process which establishes, in fact the identity of these two identities. Your identity is who you are. So an identity crisis is when you either lose track of who you are or do not feel happy with who you are and want to change your life or restructure it. A major transformation in a person's personality and the way he/she do things may occur if he/she has an identity crisis.

Hence, identity is inherent in all levels of human organizations namely personal, family, community, ethnic group, the local government, the state and the entire country as a whole; within the confines of this identity, everybody sees one another as brothers and sisters and therefore does almost everything in common. They 
structure and organize their lives to conform to the society's way of life and cooperate to ensure the general progress of the community. When this happens they are seen to be identifying with their society. When we talk of national identity emphasis is no longer on identifying with the family, ethnic or religion, but on national identity as a belief in membership of a nation state. People no longer look at themselves as belonging to any component unit within the country but as belonging to the country (Nigeria).

When a person is endeared to his country and is ready to or in most cases has sacrificed himself/herself for the interest and sake of his/her country, that person has exhibited a high level of patriotism and is said to be patriotic. Such persons who have sacrificed their personal interests for the common good of their country are said to have developed a strong feeling of patriotism which results in national identity. National identity could therefore be defined as the feeling of love and pride which a citizen has for his/her country. It is attitudinal in form and perceptual in content. It represents to some extent the subjective dimension of a national behaviour. The members of a country identify nationally when they are proud of their country and consequently are inward looking. Their attachment to and pride in the nation reflect their identification (Mamser, 1989: p. 177). Thus, in matters of national concern, citizens are seen exhibiting some measures of national identity. By national integration we mean the development of an integrated and coherent national identity and consciousness in a multiethnic society in which all citizens is given a fair opportunity to achieve his/her maximum potential. Members are given sense of belonging irrespective of where he/she comes from. National integration enhances the chances of creating higher loyalties that supersede parochial loyalties to ethnic cleavages. Ethnicity and ethnocentrism with its attendant cultural differences, has been a great hindrance to this dream. National integration in a multiethnic society theoretically is a process of building a new society and social order based on justice and fair play to all its members no matter the ethnic group, language or religion. At the socio-economic level it requires that socio-economic progress be made within the democratic framework of sharing political and economic power equitably with the minorities.

Social integration includes acculturation which is the process of cross-culturalization, which Dukor (2003) explain as the process of cultural social integration in a society of religious and cultural diversity. It involves intercultural borrowings marked by continuous transmission of traits and elements among diverse peoples resulting in a new and blended pattern. It is a synthesis of diversity in unity. An acculturated and socially integrated person is one that has an inner rhythm, a sustainable fulcrum with norms that bind the society with its polity in norms and nuances, intelligible to both the leader and the lead (Dukor, 2003). He suggested that proper acculturation within a multiethnic country like Nigeria will remove ethnic differences and enhance national identity and integration. This is because if citizens are cultured, then the nation will be cultured; there will be national identity and social stability in the country.

\section{Concept of Multiethnic Society}

The term ethnicity is a complex phenomenon and extremely fluid in reality (Anugwom, 2000; Odeyemi, 2014). It generally refers to characteristics of a human group having distinctive racial, religious, linguistic and certain other cultural traits in common and tends to cut across continental boundaries. Nnoli (1980) describes it as a social phenomenon that is associated with interactions among members of different ethnic groups ... distinguished by the communal nature of their boundaries. An ethnic group constitutes social formations which are identified by their communal factors that include mainly language, religion or culture or both. They are marked according to Uno Ijim Agbor (1999) by distinct linguistic and/or cultural similarities with common consciousness and identity which expose them to a consciousness of being one in relative difference to other ethnic groups. This consciousness could originate from several antecedent developments spanning over years. Nnoli (1980: p. 168) maintains that "such consciousness could arise from inter ethnic competition for scarce valuable resources, and this has been seen to form the basis of ethnic consciousness in Nigeria and indeed Africa." It would suffice to say here that this inter-ethnic competition breeds conflicts especially in the context of prevailing economic recession; where scarce resources are rigorously competed for by the various ethnic groups. Nnoli further argues that the conflicts arising from this competition become pronounced especially in a society where inequality is held uppermost in societal relations and wealth is grossly considered as sine-qua-non for attaining social respect. These incessant and uncontrolled conflicts are contingent on the fear of each ethnic group not to be confined or encapsulated within the lower limits of inter-ethnic echelon of socio-economic inequality.

The resultant effect is of course a divisive and destructive socio-economic competition with its attendant and 
antisocial shortcomings. The selfish drive therefore by each group to limit competition to their advantage is expressed in the use of hostility towards the other ethnic group. The behaviour and actions of ethnic groups are contingent on the resources they look forward to control. Banerjee \& Sengupta (2009) reported that more than 10 million lives were lost between 1945 and 1975 to ethnic militia violence around the world. In contemporary Nigeria, with more than two hundred and sixty (260) ethnic groups (Peil, 1976: p. 73) scattered all over the country, their attitudes are reflection of history and therefore, with a recourse to history they employ more effective avenues as means of competition so as to gain competitive advantage over others. This is expressed in the emergence of contemporary ethnic system based on competitive mistrust, hence, in a multiethnic society like Nigeria the competitive short term tactics and long term strategies they employ are function of history and of the resources they seek to control. Ethnic groups with more effective tactics and strategies normally gain competitive advantage over the other groups. Thus, Osaghae (1994: p. 44) stress that "ethnicity is a conscious behavior based on the ethnic identity or loyalty in a competitive situation involving more than one such identity, which is aimed at furthering interests of the individual and/or group”. In political terms Uwa \& Co (2013: pp. 79-86) explains it "as ethnic identity based behavior which seek in a competitive setting to capture political power at the micro level and state power at the macro level.” Thus, ethnic groups in the words of Salamone (1997) promote an ideology that ... asserts a common ancestor for all members, a common set of values, culture, behaviour and ideology. Similarly, Odeyemi (2014: p. 4) asserts that ethnic groups are political, economic, and social action groups formed for a particular purpose that is to obtain something that is more easily attained by belonging to an ethnic group than as an individual or as a member of some other ethnic group. Hence the ethnicity can be viewed as the characterization of ethnic relations per time in any multi-ethnic social system and which usually are frictional and opposing. Consequently, most multi-ethnic states in Africa are in what Odeyemi called "a flux of nagging competitions.” In this type of scenario therefore the need for conscious inculcation of national identity and patriotism cannot be postponed.

\section{National Identity as a Foundation for National Integration}

Nigeria as a country is richly endowed with both natural and human resources to propel her to higher economic, social and political heights. What prevented and is still preventing this take off has been spotted by many analysts to be Nigerian's weak national identity and lack of social integration. If the citizens develop a high level of national identity, the country can confidently defend and protect the interest of the entire African continent. This is because Nigeria is naturally endowed and blessed with abundant natural and human resources and if properly harnessed could justify the country's claim of being the "giant and biggest economy in Africa". National identity therefore brings about progress. Any country needs the love and support of its citizenry to survive. In multiethnic country like Nigeria, weakness sets in when the citizens become apathetic towards their country. This indifference to national affairs retards progress and drags the nation backward. Progress and development of a strong and virile nation can be seen only when the citizens shows strong love and commitment to their country. It is only when this is done that the country is sure to be moving towards a united, a strong and developing nation.

It is in recognition of the above factor that most democratic nations promote in their constitution; love of the country by providing for the welfare of the people, for it is only when the welfare of the people is guaranteed that they in turn will identify with the country. The 1999 Constitution of the Federal Republic of Nigeria takes cognizance of this when it stated that "the fundamental objectives and directive principle of the government policy should be to promote the people's welfare and that the people are supreme and that is to say sovereignty belongs to the people." It further states that "the security and welfare of the people shall be the primary purpose of government." It is therefore in recognition of the non implementation of the above constitutional provisions in our national life that we now turn our attention to the factors that militate against Nigeria quest for national identity and integration.

\section{Factors Militating Against National Identity and Integration in Nigeria}

One of the major factors militating against an ideal national identity and integration is the heterogeneity of the ethnic groups that made up Nigeria and the interethnic jostling for the control and distribution of national wealth. On ethnicity, many scholars write that Nigeria is such a multiethnic, linguistic and religious community, where traditional social structure as well as the imposed western and oriental ones provides such a mosaic effect that to call it a pluralistic society sounds like an understatement. J. Gunther as far back as 1955 observes in this direc- 
tion that "the lack of homogeneity is beyond doubt its (Nigeria's) overriding political and national problem. The curse of this great country in fact is sectionalism. Nigeria is a geographical monstrosity-three country in one.” Secondly, any meaningful attempt to understand the crisis of national identity and integration in Nigeria has to be historically contextualized in terms of system of rule and domination instituted by the Colonial powers. The Colonial Government clearly marked out the critical role it is to play in the process of ethnic identity formation and the political use to which such identity or consciousness is going to be put. This is strongly suggested by the rich literature on the role of Colonialism in the promotion and even invention of ethnicity in Nigeria (Nnoli, 1978; Rangers, 1993; Anugwom, 2000; Orji, 2001).

Odeyemi (2014: p. 9) concludes that "the failure of the various tribal groups to negotiate their amalgamation is the root of many tribal wrangling and agitations, ethnic hues and cries of marginalization, greed, controversial and inconclusive censuses, vote rigging, stagnated economic growth and nepotism in Nigeria, and not necessarily its huge territorial and population size with its multifarious ethnic groupings."

The British colonial political strategy of "divide and rule" as noted by scholars like Oni et al. (2008), Onwudiwe (2011) which was aimed at introducing the legacy of transforming the existing flexible and fluid identity relation between the various ethnic groups in Nigeria to one based on rigidity was clear indication of their double barrel intention. They achieved this by relying on the often biased research findings of colonial anthropologists in ranking the ethnic groups on the basis of their physiognomy and culture as perceived to be suitable for their quest for domination. Kuna (1998: p. 83) comments that the construction of a Northern Nigeria identity from the inception of colonial rule was rigidly defined as "Islamic" and "Hausa", thus elevating these social categories into a more politically dominant position within the area. Colonialism so to say played a unificatory role in the amalgamation (not unification) of the different ethnic groups of Nigeria into one country, but it equally sows the seed of disintegration by the structural disunity it instituted administratively and legally. Until 1914 the colonial masters ruled Nigeria not as Nigeria, but as disparate nations at least four: the colony of Lagos and three protectorates the West, the East and the North. This was so distinct to the extent that national frontier were demarcated between these. Even an agreement was signed and rigorously implemented that hindered any southern penetration to Christianize the North. Direct efforts were even made by the British to encourage, not national but regional thinking. The constitution gave enormous autonomy and control over resources to each of the regions.

The 1951 Mcpherson constitution for instance made the regions the more important centre of political life. Since the regions correspond to the ethnic groups, Nigerian politics became ethnic politics both in form and in result. In the words of Diamond (1988) election campaign was characterized by blatant appeals to ethnic prejudice and vituperates rhetoric. The Federal system, created by the 1954 Constitution of Littleton did not seem to diminish the rising ethnic conflicts all to the advantage of the colonial government. The thinking of many analyst of Nigeria historical development is that the colonial government did not want such conflict to diminish fast as it distracted the people from coming to the center to demand leadership cum political independence. Nonetheless, this demand had to be made. The first general election was conducted in 1959, which paved the way for Nigeria to receive her political independence from Britain the following year, but the loaded gunpowder of tribal politics of bitterness was set for explosion and this happened in 1966.

The first military coup-d'état in Nigeria was as a result of extreme ethnocentrism and political corruption of politicians in the corridors of power. Since then till now Nigeria's has not grown out of this hydra headed ethnocentrism in her political, social and administrative life. It led to the Nigeria-Biafra civil war and the collapse of the first Republic and subsequent coups and counter coup.

Thirdly, ethnic politics has created a deep-rooted structural inequality in the distribution of education, employment and sharing of power. This has resulted in what we may describe as individual, tribal and regional, religious and at times gender ethnocentrism. There is on the individual level a colossal dearth of fair and equal participation in national life. Those who happen to be in power (political and economic) corruptly enrich themselves from the public treasury. This has few wealthy people in the midst of the poor majority. Educational inequality is at three levels, the first being the historical fact that the Northern Muslim leaders for fear of converting their faithful to Christianity were initially reluctant to allow western Christian missionaries to introduce western education and have today come to be legally recognized as educationally disadvantage area which is used as criteria for admission in all government own educational institutions. The other being that while some southern Nigeria ethnic groups or regions have free education programmes for their members others do not. 
Hence in those regions without free education only those families who are wealthy can afford to pay for the education of their members. From the above one can see that there is a total absence of equality of opportunity in Nigeria right from the start. The same inequality of opportunity rules in the realm of employment with the entrenchment of federal character which sacrifices merit at altar of mediocrity. Merit is replaced by family, ethnic, or religious members or what Anadi E. (1982) called bribing power and friendship.

On the religious side, the external elements of colonization with its Islamization and Christianization side projects according to Iroegbu (1996) played its own part in creating its own conflict. African traditional religions never quarreled or conflicted among themselves as is the case with the European and Eastern religion. Islam from the East is a vowed opponent of Christianity from the West. And Christianity is involved in internal conflicts between its denominational parts that were imported from Europe and America. However the sharpest point of conflict now is the renewed attempt by Muslim fundamentalist to Islamize Nigeria through the large scale introduction of Sharia code of law and terrorist activities of Boko haram in some parts of Northern States in Nigeria (Odeyemi, 2014). Even in official government circle, the government that proclaims its fidelity to the secular character of the state is seen to be patronizing the Islamic religion at the expense of other religions. These hinder the emergence of national identity and integration of Nigeria multiethnic diversity.

Another factor is what determines the citizenship of a state in Nigeria. Geo-ethnicity is used to determine one's citizenship of a state. For instance, a child whose parents come from Anambra state which is in southeastern part of Nigeria dominated by Igbo ethnic group, but was born and brought up in Lagos southwestern Nigeria dominated by Yoruba ethnic group cannot be considered as an indigene for any benefit in Lagos even though his/her parent lived and paid their tax to Lagos state government, because he/she is first considered to be an Anambrian. If he/she is not careful he/she may lose his/her rights and privileges in Anambra because the child lacks, contact there. Where this happens, the child may be thrown into a very hopeless dilemma which can bring about disillusionment in his/her entire life. While, of course this may contribute to the development of state identity, it could be considered to be detrimental to national identity. Similarly, the issue of leadership in Nigeria and the orientation and behavior of elite and politicians present a serious challenge to national integration. The Nigerian state has had ill luck of parading and recycling selfish and inept leaders who operate along ethnic lines and sectional loyalties. While in office, they concentrate the allocation of national wealth on those from their ethnic region thereby discarding Nigerian nationalism and the inculcation of national identity and integration. They show a high level of insensitivity to the yearnings and aspiration of the citizens. Because of government's unresponsiveness to the issues of citizens' welfare, the people begin to look for other avenues to survive. These other avenues could be dysfunctional to national progress and inimical to national identity and integration.

Ethnicity is held so sacrosanct that even the elite whom one would ordinarily think that their behavior and attitude to national issues would be conditioned by their universalistic orientation occasioned by their level of education and wider experience rather profess and practice it very deeply. It is very clear that the elites of Nigeria involved themselves more intensely in ethnic power play than other people within the middle and lower echelons of society. Peil (1976) identifies three major factors responsible for the inclination of the elites to ethnic antics. She stated first that "ethnicity may be more important to them than to people with lesser opportunities. The society is believed to function as a series of ethnic power groups; and potential elite feel the need to join one of these in order to succeed: secondly, politicians finds it difficult to win votes by universalistic appeals to ideology, rather a communal war cries were popular and successful. Thirdly, there were many things which went wrong in the system and ethnic "scape-goating" was a useful way of easing pressure for reform". In fact what has been called tribalism or the so-called marginalization by some ethnic groups is seen to be part of the mechanism through which the political elite maintain itself in power and exercises its influence. Ethnic manipulation therefore is an attitude of elite behavior.

Thus Dudley (1973) asserts that the elite became the chief proponents and purveyors of parochialism and particularistic values. Every prospective elite therefore believes that a strong inclination to ethnic chauvinism will avail him of most of the opportunities he wants. With this in mind, the particular pattern of seeing ethnicity as the quickest way out of some prevailing personal or communal problem is established. This, belief of course establishes self interest in his mind and therefore convince him to believe that ethnic or sub ethnic identification can easily expose him to some opportunities. Odeyemi (2014: p. 10) observed the above trend when he states that the elites keep themselves in political office by playing and preying on the ignorance and the fears of the poverty stricken majority of their people. Thus, the elite use the ethnic factor to retain themselves in office as 
political leaders, directors or managers of national corporations and parastatals by making false claims of representing their ethnic groups. Even when they do not perform well in political office, they deceive the people by whipping up ethnic sentiments; raising fears and tensions of the threat that would be posed to their ethnic group if other groups should gain political ascendancy.” The resultant effect is indifference toward national concerns. National identity and integration under this condition cannot be attained.

The last in our list of the numerous factors is what some scholars call "cultural imperialism" which is often describe as the infiltration of western culture into the African indigenous society. This is done through the use of foreign educational materials like, films, books, internet and other publications and programmes from the print and electronic media which profess the western/American attitude to life as the original and modern, and therefore, the best. The worst aspect is that the youths pick the negative ones that expose and promote selfishness, violence, immoral and individualistic attitudes. These behavioral attitudes and orientations are not acceptable to most Nigerian ethnic cultures. In fact, those who live in Nigerian cities today suffer from cultural confusion. They now prefer foreign goods to Nigerian made ones. They do not identify with indigenous productions. The clothes they put on, the food they eat and even the values they prefer are very much foreign. A people who do not respect their cultures and values are a people without identity. Such people therefore cannot be assumed to show patriotism and loyalty to their country. Hence, we turn our attention to existentialist principle of "inter-subjectivity” as an antidote for resolving Nigeria identity problem and crisis of integration.

\section{Existentialism as an Ideology for Resolving National Identity and Crisis of Integration in Nigeria}

Our choice of existentialism as a philosophy for achieving national identity and integration is based on the assumption that it has an inbuilt ontological and moral dimension that holds the key to the resolution of national identity and crisis of integration in a multiethnic society. Hence, our intention in this paper is to argue that a critical interpretation and application of existentialist inter subjective principle expressed in various themes by Heidegger, Sartre, Merleau-Ponty, Buber, and Gabriel Marcel can be applied as an ideology for achieving national identity and integration in a multiethnic Nigeria. Before, we delve into this let us briefly discus the central theme(s) of existentialist philosophy.

Existentialism is a philosophy of man and his existential realities. It takes off from the individual's stand point and it is opposed to objective, rationalistic and system building approach in providing solutions to the problems of the absurdities of life in which man is enmeshed (Oyeshile, 2005: p. 25). For most existentialists human being is assumed to live an authentic life by playing the role of an actor rather than that of a spectator in the issues of life and existence. Even though, existentialism has its ancestry in the works of the Sophists who claim that "man is measure of all things" and Socrates who insists that "man know thy self," their doctrine will be applied here through the works of the modern existentialist earlier mentioned above for lack of space.

The national identity and crisis of integration in multiethnic Nigeria fits correctly into the existentialist perspective in crisis management for two related assumptions: The first is that both individuals and ethnic groups in Nigeria are self centred in pursuit of their natural inclination to the law of self preservation in the midst of competition for scarce resources and authenticity. The above factor is similar to the existentialist project of individuality and subjectivity in which Dasein, Pour-soi, cogito, self etc is given a prime place in the world.

Secondly, both the individual and ethnic groups in Nigeria pursue their goals to the exclusion of the general welfare of others, which negates the quest for national identity and integration. This though, at variance with the tenets of existentialism in the sense that existentialist philosophy has an inbuilt regulator of human freedom which is found in intersubjectivity. In other words, when we pursue the concept of individual freedom to its logical conclusion, we will discover that it allows for the freedom of others in spite of impression to the contrary. This can be found in Sartre's assertion that "when I choose for myself, I also choose for others" and in Heidegger's assertion that "Dasein is not only a being-in-the-world, he is also a being-with-others." (Unah, 1996: p. 60).

The implication of the above is that man is not only constituted by his project and his relations with the things which he makes use of, he is also related to others, because, others are also beings-in-the-world just the same manner like himself. This implies that whether as an individual or ethnic group saddled with particular projects and peculiar means of achieving them, we are related to others who are also being-in-the-world. Thus, Heidegger emphasized this point when he notes that when a man appears on the scene of existence, he is immediately 
aware not only of objects, but of other human beings as well. Hence, his existence is necessarily tied to the existence of others. Thus, in terms of survival, the individual must pursue goals and projects such as will make possible the survival goals of others. Hence, for Dasien at both individual and ethnic group level, survival is only possible if and only if he recognize the importance of others not as mere objects standing in the way of achieving our goal of survival, but as ends in themselves who are not only important, but also inevitable and inescapable in the realization of our goal of survival and freedom.

Similarly, Jean Paul Sartre (1905-1980) has within the frame work of his existentialism some essential ingredients necessary for the accommodation of the "self and others" thereby making it possible for us to apply his thoughts to the resolution of national identity and crisis of integration in multiethnic Nigeria. A critical analysis of his major works like Being and Nothingness, Existentialism as Humanism, and Critique of Dialectical Reason, may lead one to such summation as the "I owe its existence to others" because even though individual's autonomy is defined through his freedom of choice, when as an individual, "I choose, I also choose for the rest of mankind."

Lowen (1999/2000: p. 60) comments that "Sartre saw clearly the relation of freedom to "others" and to the world - the role others play in promoting a person's self awareness, that is our dependence upon one another." This existence of others is arrived at through man's subjectivity, which Sartre identifies with the notion of shame: "Shame is shame of oneself before the other. These two structures are inseparable. I need the other to realize fully the structures of my being. The for-itself refers to the for-others." (Sartre, 1958: p. 222). What the above passage implies is that through the concept of shame, I am being watched by somebody. The person who watches me is feeling like me as being watched by someone else. It is obvious. Therefore, that Sartre's subjectivism adequately provides for the existence of others consciousness in the world. Even though, he believes that the self must be first before the others as a precondition for having consciousness of himself and others as being for him.

Oyeshile (2005: p. 36) comments that "what all these show is that as individuals and groups we have our various latent and manifest identities, we cannot over look the importance of others and we must be prepared to accommodate them, because it is when we accommodate them that they will also accommodate us. This also lends weight to human solidarity in spite of the subjectivity embedded in Sartre's existentialism. This is so because a man who discovers himself through the cogito also discovers the others as the condition of his own existence.” This implies that existence of others can be located within the subjectivity of the individual. Hence, when I choose what is favorable to me through my subjectivity, I choose the same for others because I do not live in isolation from others. The existence of others indirectly establishes my own existence because the other and I are linked together in some activities in the society.

Thus, Sartre (1976: p. 155) asserts that "I cannot obtain any truth whatsoever about myself except through the mediation of another. The other is indispensable to my existence and equally so to any knowledge I can have of myself. Under these conditions, the intimate discovery of myself is at the same time the revelation of the other as a freedom which confronts me ... we find ourselves in a world of inter-subjectivity. It is in this world that man has to decide what he is and what others are.” The implication of the above passage of Sartre is that existentialism has the inbuilt capacity of providing a veritable ontological and ethical foundation for group solidarity and understanding which is presently lacking in multi ethnic Nigeria. Lowen (1999/2000: p. 60) while commenting on Sartre's affirmation of group freedom of which the individual is an inextricable part affirms that "he (Sartre) urged that our lives will have meaning by human beings loving and supporting each other in this world, and working together to create their common humanity by constructing societies that fulfill the need of all. True humanism, Sartre stated should take these needs as its starting point and never deviates from them. True humanism can be built only upon the mutual recognition by men and women of the human needs and of their right to their satisfaction.”

What we can draw from the above is that existentialism of Sartre supports human solidarity irrespective of our environmental and cultural differences. Hence if we look at the multiethnic diversity of Nigeria the need for human solidarity and symbiotism preached by Sartre arises because no ethnic group posses all it takes to be self sufficient, as Oyeshile A.O. rightly remarks "in Nigeria ... the ethnic region where oil resources abound, does not produce hydro-electrical resources, hence, the need for interdependency at various levels.” Similarly, Merleau-Ponty (1908-1961) advocates for the unification of the "phenomenal field" in inter-personal relationship. (Low, 1996: p. 382). It is this phenomenal field that enables an individual to unify his experiences with that of the others. The reason for this is that there is a unity in the phenomenal field to which both the world and the in- 
dividual's lived body contribute. Merleau-Ponty assert: "rational agreement is possible for human beings because their experiences open to and intersect in a shared phenomenal field. Rationality is nothing other than this blending of lived bodily profiles of mine within me I actually open upon the world together.” (Low, 1996: p. 362). The implication of the above passage in relation to our topic under discussion is that the possibility of rational agreement, which is necessary in ethnic relation rests ultimately on the structure of the human body and the simple fact about the human body is that "it is similar in all members of the human species and that these bodies open upon one sole world in a similar way.” (Low, 1996: p. 382). Hence, our bodies has the same ontological shared experience of the world like any other body, which implies that our bodies have the possibility of rational agreement and universality on which we can manage the differences that arise in individual and group relation that usually leads to conflict and crisis in multiethnic society. Thus, we can use this as the basis for addressing the problem of agreement and consensus among various ethnic groups on the ground that rational agreement is based on our ontological attachment to the world.

In the same line of thought Martin Buber in his book I and Thou provide another veritable avenue to resolve the problem of national identity and crisis of integration that arise from interpersonal and inter-ethnic relations in multiethnic society. The underlying assumption of his theory of "I and Thou" and "I-it" relations is that one is a proper human being only when one sees himself in relation with other human beings. Thus, he asserts that "the essential things are not that one makes the other his object, but the fact that he is not fully able to do so." (Buber, 1980: p. 351) it is therefore only in partnership that one's being can be perceived as part of an existing whole. This is similar to Heidegger's Dasein, Sartre's Pour-soi and Merleau-Ponty's phenomenal field discussed above.

The I-it relation is unholy and depersonalizing as it treats other individuals apart from the I, as mere objects or means to be used in achieving one's life goals. It is an instrumentalist relationship. While the I-Thou relationship is mutually affirming. It upholds reciprocity and respect for others as against the I-it relationship, which aim at degradation, manipulation and exploitation (Rader, 1980: p. 365). The I-Thou relationship upholds the belief that a person is fully a person in relation to other persons. In this line of thought you are not a real person so far as you regard others as mere things or as mere objects or implements. Thus, the real meeting between individuals comes about only when each regards the other as an end.

Hence, Buber asserts that "the participation of both partners is in principle indispensable." (Buber, 1980: p. 351). He further contends that "if genuine dialogue is to arise, everyone who takes part in it must be willing on each occasion to say what is really in his mind about the subject of conversation.”(Buber 359)Thus one can observe from the above the need for us irrespective of our ethnic origin to break away from our narrow individualism to interpersonal fellowship. Such virtues like mutuality, everyone as an end, interpersonal fellowship and dialogue should be cultivated as the basic principles of interaction among ethnic groups in multiethnic society like Nigeria that will eventually transform into genuine national identity and integration. Because when the I-Thou relationship is applied as the basis for coexistence it would then be possible to address the problem of justice, equality, peace, security and development.

Gabriel Marcel (1889-1973) even though he focused his analysis of human situation mainly on how the individual grapples with "being and having" as well as on "problem and mystery," he however, gives attention to social relations in his existentialism. For him human beings are the only being that can make promise and being able to make promise inevitably places one into a unique relationship between him and another. In doing this he invokes the concept of fidelity as a guiding principle. Thus Stumpf (1989: p. 495). While interpreting Marcel comments that "ones being can only be affirmed therefore through fidelity in so far as one responds to a world that makes demands and in which one assumes responsibility."

Thus, in Marcel's existentialism we observe a philosophy of inter-subjectivity in which man is not only related to the world but to others as well. And because man has to grapple with the problem and mystery of existence, he has to take adequate cognizance of other beings. The central notion of participation and relatedness in existence therefore forms the basis of cordial and mutual relationship, which as it were can be a recipe for harmonious coexistence among the various ethnic groups in Nigeria.

\section{Conclusion and Recommendations}

In sum, our focus in this paper has been on how the existentialist notion of inter-subjectivity construed in various terms can be applied to resolve the national identity question and crisis of integration in a multiethnic Nigeria in other to achieve national unity and sustainable development in a country that is in urgent need of human 
and material development. Hence, we argue that the various existentialist prescriptions as palatable as they may be toward resolving the above problems may likely amount to little if its application is not predicated on certain ingrain democratic values like rule of law, justice, equality, fairness and freedom. Thus, in our context the above values can only have meaning in a context of the existentialist inter-subjectivity where different ethnic groups accept one another not just as an end but as a strategic partner in the quest for survival in the midst of available scarce resources. Hence, Kalu, (2005: pp. 31-32) advocates and I agree with him that "while democracy as a mechanism of governances is not mutually exclusive with such ideologies as liberalism, authoritarianism and /or other ideological variants, most agitations in Nigeria are about participatory rights within the context of liberal constitutionalism that guarantees citizenship as the dominant identity, political and economic freedoms of action. And as long as those rights are not constitutionally guaranteed and protected, the type of regime in power will not assuage the memories and sources of agitations.” The above passage implies that no ethnic group in a multiethnic state like Nigeria should be marginalized in the sharing of power and resources of the state, as well as no group should be accorded preferential treatment in reward and punishment.

Finally, the Nigerian state should not totally discard the traditional communalistic living embedded in most cultures of the various ethnic groups, which inculcate on the individual the values of "we" survival which has been so neglected due to the agitation for power and economic resources as a veritable means of achieving national identity and integration. Beside, historical, ethnological, archeological, linguistic and of recent genetic studies have shown that much is common to the present Nigerian ethnic groups. Both archeological and oral tradition shows that there are aboriginal people living within what has now become a Nigerian boundary. The idea of a pure ethnic group or language may as well be a myth. However, while some ethnic groups share similarity in language, others have different languages (Chukwuma, 1967). In addition, numerous languages are traceable to certain basic roots. While Adeniran (1985) maintains three, Isichei (1983) has five family-groups of languages. Genetic studies also show the same result of unity. There is an intermingle of blood groups as a result of migrations. Recently, this is traceable to what Isichei calls "a common gene pool".

Cultural and artistic similarities are also evident. Traditional religious cults, masquerades, artistic artifacts like carving, orchestras, calabashes, trumpets or giant gongs, ceremonial dances, rites, and festivities, cultural and secret societies like Ekpe, Okonko, Ozo, eyo and other titles are quasi-universal elements among the ethnic groups of Nigeria; of course with particular colorings, names and differences in varieties and significations. Traditional religious cults among different ethnic groups carry with them a deep sense of the transcendence of piety, devotion, and reverence for the sacred all through the ethnic groups. Close to these are universal cultural, social and moral values: the large or extended family system, the deep spirit of fraternity, communal solidarity, spontaneity, care and concern, the presence of participation and belonging (the group spirit), and patriotism. Others include the moral values of truth, fidelity, justice, courage and respect. They are sustained by a high moral code sanctioned by the gods. In fact, these common elements vibrate from and at the same time, sustain common mentality of a "we-feeling" which defines all other values as evident in traditional cultures of various ethnic groups that made up Nigeria.

Again, the socio-political structure of different ethnic groups manifests this common spirit though differing in external structure which varies from the fairly organized Hausa Fulani emirate of the North, via the sizable kingdoms of the Yoruba and Edos in the West, to the small autonomous or semi autonomous groups of the middle Belt and the East. They all have a basic similarity of being founded from a point of departure in nuclear kinship structure. Coleman (1985) puts this central point thus: Kinship government, at the linage level and below is basically the same through Nigeria. It is at the higher levels of the traditional political structure that wide variations are to be noted. Isichei (1983) also concludes her account of primordial elements of unity thus: All these various elements - the related languages, the common gene pool, and even same widespread cultural complexes, reflect the fact that modern Nigerians are descended from a common storage population. In the remote past, the size of the population is very small and consisted essentially of small scattered hunting bands. However, while these elements of similarity are not conclusive, there are credible pointers of a primordial relationship of the Nigerian ethnic groups in culture and values. To the objection that these and other elements like religiosity, community spirit etc. are not exclusively Nigerian but are also found in most part of Black Africa, one may reply that their being African does not make them "unNigerian". Nigerians share these elements in common and as a contemporary political entity. It is our tasks to articulate these common elements and values as a starting point of a viable political theory; which can be applicable to Nigeria as well as to other African nations taking into account the specificities of each nation. 
Thus, we conclude that the problem of national identity and crisis of integration is put into focus not necessarily by ethnic diversity but by the contemporary problem of injustice especially that of consistent marginalization of some groups within the polity. Hence, we agree with Owolabi (2003: p. 2) that "the legitimate survival and integration of a nation state depends on how far the state as a legal institution can perform its role of distributing benefits and burdens among groups justifiably without any group feeling justifiably aggrieved." We therefore recommend that both Federal and state government in Nigeria should respect fundamental human rights of its citizens irrespective of ethnic origin and expose its activities to constructive criticism. It should desist from harassing people who criticize its activities. Political victimization of people should be discouraged drastically so that the government can enjoy the support across the diverse ethnic groups.

The executive legislative and judiciary arms of government must as a matter of urgency realize that Nigeria has come to the stage where emotion, personal and sectional interest must give way to a deep reflected critical thinking toward laying a solid foundation for a just, united and stable society. We must therefore reorder our thinking and begin to look inward as we embrace Nigeria as our only country. Nigerians expect the National Assembly to start the process of amending the constitution in some areas like the operation of true federalism, constitutional democracy, based on more efficient and cheaper system of government and a country where rule of law is ultimate. Nigerians expect the national assembly to pass bills that will strengthen class ties that will subvert the strength of ethnicity in contemporary Nigeria. This is because it has been observed by scholars in this respect that the strength of ethnicity lays in the structural weakness of class phenomenon in Nigeria (Otite, 1996). Thus, it is apparent that development of class consciousness with its inherent horizontal inter-ethnic linkage will create webs of social relationships capable of reducing if not eradicating the problems of ethnicity. In this case, it is expected that, politico-economic ties will be developed and promoted by inter-ethnic and multi-ethnic associations and their new symbols.

\section{References}

Adeniran, B. (1985). The Origins of the Nigerian Peoples. In R. Olaniyan (Ed.), Nigerian History and Culture (pp. 45-65). London: Essex Publishers.

Anugwom, E. E. (2000). Ethnic Conflict and Democracy in Nigeria: The Marginalization Question. Journal of Social Development in Africa, 15, 61-78. http://dx.doi.org/10.4314/jsda.v15i1.23854

Banerjee, S., \& Sengupta, P. K. (2009). Ethnicity, Nationhood and the Irrelevant State: Issues in Governance and Public Policy. The Icfai University Journal of Governance and Public Policy, 4, 85-101.

Buber, M. (1980). Elements of the Inter-Human. In M. Rader (Ed.), The Enduring Questions: Main Problems of Philosophy (4th ed., pp. 351-450). New York: Holt, Rinehart and Winston.

Chukwuma, M. (1967). Nigerian Politics and the Role of Religion. Bonn: Bonn Publishers.

Coleman, J. S. (1985). Nigeria Background to Nationalism. Berkeley and Los Angeles: University of California Press.

Diamond, L. (1988). Democracy in Developing Countries. Africa, Vol.2, London: Lynne Publishers.

Dudley, B. J. (1973). Instability and Political Order: Politics and Crisis in Nigeria. Ibadan: University of Ibadan Press.

Dukor, M. (2003). Philosophy and Politics: Discourse on Values, Politics and Manpower. Lagos: Malthus Press.

Elebeke, E. (2010). Identity Crisis: Who Really Are Nigerians? (Central Database) Export Highlight Nations/Identity Management Crisis at CTO May 12.

Gunther, J. (1955). Inside Africa. London: Hamilton.

Iroegbu, P. (1996). The Kpim of Political Communalism: Toward Justice in Africa. Owerri: International University Press Ltd.

Isichei, E. (1983). A History of Nigeria. In R. Olaniyan (Ed.), Nigerian History and Culture (pp. 20-35). London: Essex Publishers.

Kalu, K. A. (2005). Echoes of Instability: Implications for State, Society and Democratic Consolidation in Nigeria. The Constitution: A Journal of Constitutional Development, 1, 92-117.

Kuna, M. J. (1998). The Sokoto Caliphate, Colonialism and the Formation of Identities: The Construction of "Northern Nigeria”. Annals of Social Science Council of Nigeria, No. 10, January-December.

Low, D. (1996). Merleau-Ponty and the Foundations of Multiculturalism. Journal of Philosophical Research, 21, 377-390. http://dx.doi.org/10.5840/jpr_1996_9

Lowen, J. (1999/2000). Jean-Paul Sartre: Philosopher for the 20th Century. Free Inquiry, 59-60. 
MAMSER (1989). Towards a Free and Democratic Society. Political Education Manual, Directorate for Social Mobilization (Mamser).

Nnoli, O. (1980). Ethnic Politics in Nigeria. Enugu: Fourth dimension Publishers.

Odeyemi, J. O. (2014). A Political History of Nigeria and the Crisis of Ethnicity in Nation-Building. International Journal of Developing Societies, 3, 85-101.

Oni, D. et al. (Eds.) (2008). Nigeria and Globalization on Identity, Politics and Social Conflicts. Lagos: Centre for Black and African Arts and Civilisation (CBAAC).

Onwudiwe, O. (2011). North and Rest of Us. This Day, Volume 16, No. 5861, Wednesday, May 11.

Orji, E. I. (2001). Issues on Ethnicity and Governance in Nigeria: A Universal Human Rights Perspective. Fordham International Law Journal, 25, 431-456. http://ir.lawnet.fordham.edu/ilj

Osaghae, E. E. (1994). Ethnicity and Its Management in Africa: The Democratization Link. Lagos: Malt House Press Ltd.

Otite, O. (1996). Nigeria towards Salvaging a Ravaged Society. Ibadan: Dabfol Publishers.

Owolabi, K. A. (2003). Fictional Tribes and Tribal Fictions: Ethnicity, Ethnocentrism and the Problem of the Other in Africa. Ibadan: John Acher.

Oyeshile, O. A. (2005). Reconciling the Self with the Other: An Existentialist Perspective on the Management of Ethnic Conflict in Africa. Ibadan: Hope Publications.

Rader, M. (Ed.) (1980). The Enduring Questions: Main Problems of Philosophy (4th ed.). New York: Holt, Rinehart and Winston.

Rangers, R. (1993). The Invention of Tradition Revisited: The Case of Colonialism in Africa. In T. Ranger, \& O. Vaughan (Eds.), Legitimacy and the State in Twentieth Century Africa (pp. 209-320). London: Monithers. http://dx.doi.org/10.1007/978-1-349-12342-1_3

Salamone, F. A. (1997). Ethnicity and Nigeria since the End of the Civil War. Dialectical Anthropology, 22, 303-333. http://dx.doi.org/10.1023/A:1006814508211

Sartre, J. P. (1958). Being and Nothingness. London: Methuen\& Co. ltd.

Sartre, J. P. (1976). Existentialism Is Humanism. In A. Castell (Ed.), An Introduction to Modern Philosophy (3rd ed., pp. 55-79). New York: Macmillan.

Stumpf, S. E. (1989). Philosophy: History and Problems (4th ed.). New York: McGraw-Hill Book Comps.

The 1999 Constitution of the Federal Republic of Nigeria. Lagos: Government Press.

Unah, J. I. (1996). Heidegger's Existentialism: An Essay on Applied Ontology. Lagos: Panaf Publishing Inc.

Uno Ijim, A. (1999). Ethnic Pluralism and National Identity in Nigeria. In G. O. Ozumba (Ed.), Nigeria: Citizenship Education (pp. 83-115). Aba: AAU Vitalis Rook Company.

Uwa, O. G., Balogun, A., \& Adenegan, T. S. (2013). Ethnicity an Identity Crisis: Challenge to National Integration in Nigeria. IOSR Journal of Humanities and Social Sciences, 16, 79-86. 